\title{
Ethics and Education
}

\section{'\#FactsMustFall'? - education in a post-truth, post- truthful world}

\section{Kai Horsthemke}

To cite this article: Kai Horsthemke (2017): '\#FactsMustFall'? - education in a post-truth, posttruthful world, Ethics and Education, DOI: 10.1080/17449642.2017.1343620

To link to this article: http://dx.doi.org/10.1080/17449642.2017.1343620

央 Published online: 28 Jun 2017.

Submit your article to this journal $\llbracket$

Q View related articles $\sqsubset$

View Crossmark data \lceil 


\section{‘\#FactsMustFall'? - education in a post-truth, post-truthful world}

\section{Kai Horsthemke}

Bildungsphilosophie und Systematische Pägagogik, Katholische Universität Eichstätt-Ingolstadt, Eichstätt, Germany

\begin{abstract}
Taking its inspiration from the name of the recent '\#FeesMustFall' movement on South African university campuses, this paper takes stock of the apparent disrepute into which truth, facts and also rationality have fallen in recent times. In the post-truth world, the blurring of borders between truth and deception, truthfulness and dishonesty, and non-fiction and fiction has become a habit - and also an educational challenge. I argue that truth matters, in education as elsewhere, and in ways not often acknowledged by constructivist, postmodernist and postcolonialist positions.
\end{abstract}

\section{KEYWORDS}

Post-truth; truth; truthfulness

'Imfihlakalo yasemhlabezi iqiniso.' ('The truth is the world's secret.' - Zulu proverb)

\section{Introduction: the decline of truth}

The phrase '\#FactsMustFall' has been inspired by the name of the recent '\#FeesMustFall' movement on South African university campuses that was preceded by '\#RhodesMustFall'. The association is significant for an additional reason, given this movement's ideological proximity to black consciousness and Afrocentrism, and its explicit endorsement of the Africanisation of higher education. Part of the latter is also a disavowal of 'Eurocentric logic', 'Western rationality' and 'Northern epistemology' (see Seepe, passim 2004; De Sousa Santos, passim 2007; Cross and Ndofirepi, passim 2017).

A further important inspiration for this paper has come, of course, from recent political events and their global impact: the stay-vs.-leave referendum in the UK, the US presidential election, the appointment of creationist Betsy DeVos as the US Education Secretary, Vladimir Putin's prevarications about the Russian arms build-up, not to mention developments in the Eastern Ukraine (e.g. the denial that there are any Russian troops there), Turkey (e.g. Recep Tayyip Erdoğan's decision to 
remove evolutionary theory from educational curricula) and Syria, and the blame games characterizing the respective situations.

Philosophy in all its forms and traditions has always been centrally preoccupied with truth. However, rather suddenly, in the last couple of decades of the twentieth century truth became unfashionable. I cannot help thinking that particular members of the academic community - certain constructivists, postmodernists and postcolonial theorists, even some feminists (see Hall and Ames 1987, 1998; Harding 1991, 1996; Quale 2008; Maffie 2009; Pennock 2010; Code 2012; Rosemont Jr. et al. 2014, and the respective emphasis on locality, subjectivity, and standpoint perspectives) - have contributed to the current climate in which truth, facts and rationality are treated with disdain. For example, the idea that truth is not objective or universal has taken hold not only of popular culture but also of politics, perhaps to the detriment of the latter. However understandable postcolonial and postmodern theorists' initial motivations may be, it appears that their choice of targets is somewhat ill-advised. Together with the ethical and the political, they have the ontological and the epistemological in their sights, which accounts for a lot of the confusion and errors. The precedence given to assorted political and ideological agendas, then, along with the rising popularity of certain 'isms' (like anti-foundationalism and standpointism) and also of pseudoscience in academia, has led to a decline of truth as both a serious subject and an intellectual tradition that began with Plato and Aristotle and became a defining characteristic of the Enlightenment.

\section{The 'post-truth' world}

After much research and debate post-truth was chosen the Oxford Dictionaries Word of the Year 2016 - an adjective defined as 'relating to or denoting circumstances in which objective facts are less influential in shaping public opinion than appeals to emotion and personal belief.' ${ }^{1}$ In this case, the 'post-' prefix does not mean 'after' so much as it implies an atmosphere in which a notion is irrelevant (see also Maffie 2009, 2014; Rosemont Jr. 2014a, 2014b). Thus, post-truth as an adjective refers to 'beyond or superseding the importance of truth; usually in a pejorative sense, uncaring of factual accuracy'. As a noun, post-truth signals the 'fact or state of being post-truth; a time period or situation in which facts have become less important than emotional persuasion'.

As early as 2004, Keyes (2004) coined the term 'post-truth era' in his book by the same title:

In the post-truth era, borders blur between truth and lies, honesty and dishonesty, fiction and nonfiction. Deceiving others becomes a challenge, a game, and ultimately a habit.

The era of truth and facts/facticity has given way to an era where emotions, inclinations and biases become significant in interpreting data. When people refer to post-truth, they seem to mean those political statements which are untouched by 
rational argument, which are held and accepted regardless of (even against) the evidence available. In this sense, they are above and beyond truth, since there is no seeming 'truth maker'. There is no actual state of affairs which can make that idea true or false.

Post-truth (or post-factual) politics denotes a culture in which political debate characteristically assumes the form of appeals to personal feelings detached from policy details, and of the frequent repetition of bald assertions to which factual counter-evidence is disregarded. Although post-truth techniques have long played a role in political campaigns worldwide, the contemporary origin of the term is attributed to blogger David Roberts used the term in 2010 in a column for Grist (Roberts 2010), where it was defined as'a political culture in which politics (public opinion and media narratives) have become almost entirely disconnected from policy (the substance of legislation)'. It became widespread during the 2016 presidential election in the United States and the 2016 referendum on membership in the European Union in the United Kingdom.

A long list of proven untruths and fabrications characterized the 'Leave' campaign prior to the Brexit vote ${ }^{2}$ and also the recent, hard-fought race for the US presidency. In a prescient 1967 essay, Hannah Arendt writes that no one'has ever doubted that truth and politics are on rather bad terms with each other, and no one', as far as she knows, 'has ever counted truthfulness among the political virtues' (Arendt 1967, 1):

Lies have always been regarded as necessary and justifiable tools not only of the politician's or the demagogue's but also of the statesman's trade. (1) ... While probably no former time tolerated so many diverse opinions on religious or philosophical matters, factual truth, if it happens to oppose a given group's profit or pleasure, is greeted today with greater hostility than ever before (5) ... Truthfulness has never been counted among the political virtues, because it has little indeed to contribute to that change of the world and of circumstances which is among the most legitimate political activities.

Arendt considers'the result of a consistent and total substitution of lies for factual truth' to be'not that the lies will now be accepted as truth, and the truth be defamed as lies, but that the sense by which we take our bearings in the real world - and the category of truth vs. falsehood is among the mental means to this end - is being destroyed' (15). Why is her analysis so topical? A democratic debate requires provable facts about which there exists agreement. The debate then concerns what actually follows from these facts. But what happens when facts themselves are not given their proper due, when there is a constant stream of lies, deflections and watering-down? The culture of debate then follows the laws of 'like' and 'dislike'. The value of a statement is not measured by its plausibility or facticity but by its potential to accumulate 'likes'. (I return to this point shortly.)

After the recent presidential inauguration in the US, White House press secretary and communications director Sean Spicer famously declared: 'This was the largest audience to ever witness an inauguration, period'. When confronted with 
the obvious inaccuracy of this statement, Trump counsellor Kellyanne Conway defended Spicer by stating that he had offered 'alternative facts'. Conway's phrase reminded many commentators of 'Newspeak', a dystopian language style that was a key element of the society portrayed in George Orwell's novel 1984. Even before Donald Trump's CIA speech, ${ }^{3}$ Spicer's first press conference, or Kellyanne Conway's attempts to spin Russian hacking, Trump's team had problems with telling the truth. Trump supporter Rudy Giuliani famously declared that before Barack Obama there had been no notable terror attacks on American soil. (This statement is made even more piquant by the fact that Giuliani was New York City mayor at the time of the 9/11 attacks in 2001.) As the independent fact-checking website PolitiFact noted, Trump made almost 200 statements during the campaign that were deemed simply false or 'pants on fire' lies. ${ }^{4}$ In the first 35 days of Trump's presidency, The Washington Post counted 133 false or misleading claims, which it catalogued and carefully refuted. ${ }^{5}$ Trump seems to suffer no negative consequences for making things up. If anything, his popularity has held steady and even increased with every accusation that he has stated a factual inaccuracy.

The interesting thing is that it is not difficult to identify these statements as lies. Even those who applaud the speakers know, more often than not, that what they have just been offered is untrue. But they do not care - because they like what they have heard. The question whether or not something relates to the facts has become irrelevant. Take Giuliani's statements about terror attacks. They are addressed to people who feel that since Obama became US president, everything has become worse, even terror. The truth of a statement is no longer significant for its value in the political arena. ${ }^{6} \mathrm{~A}$ defining trait of post-truth politics, then, is that campaigners continue to reiterate their assertions, even if these are found to be untrue by the media experts or independent researchers. Post-truth politics can also include mudslinging ('negative campaigning') and conspiracist demonization. Michael Deacon, parliamentary sketch-writer for The Daily Telegraph, summarised the core message of post-truth politics as'Facts are negative. Facts are pessimistic. Facts are unpatriotic' (Deacon 2016).

\section{Lies and bullshit}

Jeet Heer, a senior editor at the New Republic, states that 'Trump is something worse than a liar. He is a bullshit artist' (Heer 2015). Heer draws inspiration for this analysis from Frankfurt's 2005 book On bullshit. 'However studiously the bullshitter proceeds', says Frankfurt, 'it remains true that he is also trying to get away with something' (Frankfurt 2005, 23). A'fundamental aspect of the essential nature of bullshit' is that

although it is produced without concern with the truth, it need not be false. The bullshitter is faking things. But this does not mean that he necessarily gets them wrong. (Frankfurt 2005, 47-48) 
This indicates what distinguishes bullshit from lying. 'Since bullshit need not be false', says Frankfurt, 'it differs from lies in its misrepresentational intent' (54). The essential difference between the bullshitter and the liar is that the latter is intent on communicating something false as if it is true, whereas the former is indifferent to whether what he communicates is true or false. It is this very lack of concern, and a general failure to assume responsibility for the (in)correctness of one's statements, that characterizes bullshit; whether it generates mere entertainment or veritable disturbance (or even threat) varies from case to case. The 'only indispensably distinctive characteristic' of the bullshitter 'is that in a certain way he misrepresents what he is up to' (54). So, while he is not essentially concerned with presenting a false picture of the world or producing a false belief about the way things are, he is trying to present a false picture of himself or to produce a false belief about himself: namely that he knows what he is talking about.'It is impossible for someone to lie unless he thinks he knows the truth', Frankfurt observes.

Producing bullshit requires no such conviction. A person who lies is thereby responding to the truth, and he is to that extent respectful of it. When an honest man speaks, he says only what he believes to be true; and for the liar, it is correspondingly indispensable that he considers his statements to be false. For the bullshitter, however, all bets are off. ... He does not reject the authority of the truth, as the liar does, and oppose himself to it. He pays no attention to it at all. By virtue of this, bullshit is a greater enemy of truth than lies are. $(55,56)$

Frankfurt's analysis helps to explain why Trump is so unperturbed whenever he is taken to task on his bullshit. His standard response is to undermine the very possibility of fact-checking his statements. The claim that he is telling the truth but that there can be no evidence for it is in many ways more deceitful than the initial falsehood. It takes us to a post-truth world where the truth of claims is unprovable, and we have to simply accept the workings of Trump's self-proclaimed 'world's greatest memory'. In effect, he wants to take us to a realm where personal convenience and subjective estimation are all, where historical facts are simply what he claims them to be. In his bullshit world, reality is whatever appeals to him. As Heer (2015) has pointed out, Trump's background in real estate - a profession that involves making convincing sales pitches - provides one clue as to why he is such a bullshit artist. Frankfurt's analysis offers an additional suggestion: 'Bullshit is unavoidable whenever circumstances require someone to talk without knowing what he is talking about', says Frankfurt. 'Thus the production of bullshit is stimulated whenever a person's obligations or opportunities to speak about some topic exceed his knowledge of the facts that are relevant to that topic' (Frankfurt 2005, 63). As a businessman-turned-politician, Trump often seems in over his head on domestic and international policy discussions, which is perhaps the main reason why he is so disposed to bullshitting.

The misgivings by scientists, following the US presidential election, have to do with actions and envisaged policies that are already affecting scientists and related professionals originating from countries that are discriminated against by 
the Trump administration as well as Trump's vociferous climate change denialism. He is seen by many as having 'declared war on planet Earth', for good reason: he is approving pipelines, firing up coal mines, and - most alarmingly - he recently signed an Executive Order to pull the US out of the Paris climate agreement that is the global community's best shot at a clean, safe future. Even before Trump moved into the White House, US scientists were concerned with storing data and findings in safe locations, so that they could not be destroyed by Trump's agents. ${ }^{9}$ Ninety-nine per cent of all climate experts are in agreement about human-caused global warming. Yet, a few cunning lobbyists have systematically cast doubt on this view (arguing, for example, that climate change warnings are sponsored by China, to weaken the US economically ${ }^{10}$ ), until this matter of fact became a matter of opinion, a point of view. While temperatures rise globally, there are contestations and fights in many countries over whether climate change really exists.

Radical constructivists bear at least partial responsibility for this situation, in which it has been easy to peddle blatant untruths and to doubt well-established facts. Andreas Quale conceptualizes radical constructivism as a relativist epistemic approach and defines 'knowledge as story'11:

It is a fact that there are many stories.... The crucial point to note is that science is not to be considered as intrinsically more true or correct than any of these alternative stories. In this light, even the so-called pseudo-sciences are just to be regarded as different stories. (Quale 2008, 115)

But what is the status of the 'fact that there are many stories'? Is it also a story and why should this be more compelling than the 'story' of mind-independent reality and truth? Moreover, if climate change is a story and the 'North Pole' is a mere construct that has been manufactured by technical instruments, scientific discourses and politics, then how do radical constructivists respond to right-wing conspiracy theories, to climate-change denialism, and so on? If there is no objective truth, if there are no independent facts, then how does one respond to systematic distortions, fabrications, and lies?'We may live in a post-truth era, but nature does not', reads a Los Angeles Times headline on 10 February $2017 .{ }^{12}$ Clearly, realists might respond, climate change denialists should not just be called on their 'facts' but arguably also on their motivations. The economic interests being served by such denialism are substantial and seem to render insignificant those opposing it.

An altogether more favourable account of the post-truth era (admittedly preBrexit and pre-Trump) has been provided by Higgins (2013). ${ }^{13}$ Starting from the Nietzschean view that 'there is only ... a perspective "knowing"', she writes:

In place of God's eye we would have countless eyes with divided perspectives, unconsciously projecting mental preconceptions onto external reality. What results is a kind of deep pluralism - not simply the recognition of different socioeconomic standpoints, but also an acknowledgment of the ways in which these perspectives are shaped by animal instincts, culture, and ideology. If we want the fullest picture of a thing, we need to consult other people's perspectives, and the more we consult, the better. ... 
Higgins suggests that human beings should be understood to'make meaning and apprehend truth from radically different standpoints and worldviews, and that our great wealth and freedom will likely lead to more, not fewer, disagreements about the world'. 'In the post-truth era', she says,

we should be able to articulate not one but many different perspectives....

Our post-truth era, in short, need not be an obstacle to taking common action. We might see today's divided expert class, and fractious publics, not as temporary problems to be solved by more reason, science, and truth, but rather as a permanent feature of our developed democracy. We might even see this proliferation of belief systems and worldviews as an opportunity for human development. We can agree to disagree and still engage in pragmatic action in the world. (Higgins 2013)

How would one account for human development in the absence of a common commitment to rationality and truth, and what would constitute a standard for successful 'pragmatic action'? In the absence of truth, which helps distinguishing knowledge from mere belief, how would one even make sense of 'understanding'? If it is to have any meaning at all, understanding requires reference to an objective framework, to facts (whether natural or social), truth, the way things are, etc. Understanding, admittedly, is context-dependent, because it has a characteristically subjective component. Nonetheless, it obtains its meaning, its cognitive force, from its additional, essential connection with truth: it is directed towards truth, towards the way the world is. Higgins is right about one thing: beliefs and belief systems vary, but she errs in taking this to imply that 'there is only ... a perspective "knowing"', or 'deep pluralism' with regard to truth - that apprehension from 'radically different standpoints and worldviews' is all that can be said about truth. (A favourite postmodernist sleight-of-hand is to refer to 'truthS'.) Similarly, Arendt $(1967,5)$ correctly emphasizes diversity of human opinions. Yet, this acknowledgement does not, indeed cannot, require us to fetishize cognitive pluralism and epistemological diversity (see Levisohn and Phillips 2012; Siegel 2012). People's opinions and judgements differ, yet - as Ronald Beiner has put it -'they are drawn together in political argument and rational debate because of what they share: $a$ common aspiration to apprehend moral and political truth' (Beiner 2008, 32). In The Human Condition, Arendt uses the image of a table to illustrate her conception of a public world: 'To live together in the world means essentially that a world of things is between those who have it in common, as a table is located between those who sit around it; the world, like every inbetween, relates and separates men at the same time' (Arendt 1998, 52). Beiner sees this 'image of the world that simultaneously separates us and draws us together' as working

equally well to capture our relationship to truth. Our opinions divide us, but we wouldn't be motivated to formulate our opinions, articulate them, and thus share them with others unless we were participants at a deeper level in a shared quest for moral and political truth that draws us back together as a community of truth-seekers. Exercising political judgment means that holding differing opinions never separates us sufficiently to cancel out this community of shared aspiration. (Beiner 2008, 132) 


\section{Educational implications}

What are the implications for education? Studies indicate that children, teenagers, students and also adults are increasingly unable to distinguish between news and fake news, between a scientific study and a sponsored advertisement. (The latter is usually marked by the indicator 'sponsored content'.) ${ }^{14}$ What makes this even more remarkable is that the internet also greatly facilitates the cross-checking of received information. People have always been gullible and easily persuaded by data and statistics, however fabricated. Thus, the 'digital intelligence' so frequently attributed to children and teenagers is a bit of a myth, or at least only partially applicable which points to the urgent need for courses promoting internet intelligence and digital literacy that many schools have already begun to offer. ${ }^{15}$

In this regard, too, the New York Times ${ }^{16}$ recently launched its first major brand campaign in decades, a not-entirely-non-commercial campaign that

is based on a fact - that the truth matters, now more than ever. The truth, as our journalists can attest, is also incredibly hard to get to. We remain undeterred in our efforts to reveal and report the facts with integrity and courage.

The newspaper invites the committed public to share'the work and [to participate] in our student subscription sponsorship program, which brings The New York Times to public classrooms across America'.

What about the curriculum? Not included, at least not under the guise of 'knowledge', should be mere beliefs or opinions unanchored by reason/s, bald assertions, superstitions, prejudice, bias - in fact anything that involves myth, fabrication and constitutes an infringement on the cognitive rights of learners. However, it may be pedagogically and epistemically useful to teach these qua beliefs, opinions, assertions, superstitions, prejudice and bias. This would no doubt strengthen students' reasoning and critical thinking abilities, something I take - without adducing reasons - to be desirable. While something might be said for teaching strategies that are not directly truth-promoting, like playing devil's advocate or trying on an argument for size, good practice is arguably modelled by educators who pursue truth and who are truthful and sincere in their interactions with others.

Yet, it is no longer sufficient to present knowledge, to make facts available. There is also a need for second-order elucidation that - over and above transmission and mediation of contents - also provides information about their origin, how they came to be, and that advertises the rationality at work in content selection. Classical gate-keeping must be accompanied by what might be called 'gate-informing' which goes beyond selection of relevant information and knowledge to include making one's selection criteria transparent, providing information about one's sources, a self-reflective, dialogically oriented defence of relevance and plausibility, and claims to objectivity. Simply put, academics and teachers have to be prepared to explain again and again how they work and why they say what they say. Gate-informing also has to be used, without false modesty or politically correct restraint, to counteract disinformation, moral manipulation, and the like. 


\section{The post-colonialist response: 'way-centred' as opposed to 'truth- centred' epistemologies}

Against this understanding of truth and facts, and its educational implications, it has been argued that non-Anglo-European traditions place no special emphasis on 'belief', 'evidence' or 'truth' - but that, according to indigenous practitioners, it is rather 'the way' that constitutes knowledge: i.e. harmonious interaction and appropriate models of conduct (Hall and Ames 1987, 1998; Maffie 2009; Maraldo 2014; Rosemont Jr. 2014a, 2014b; Thakchoe 2014). In this regard, John Maraldo refers to Japanese philosopher Wasuji Tetsurō, who associates propositional or descriptive truth (shinri) with truthfulness or sincerity and with trust (the connotations of Wasuji's term makoto also range from fidelity and honesty to reality and factual truth; Maraldo 2014, 170, 171). It has been argued, further, that cognitive states are (to be) seen as 'maps', as useful and practical action-guides (Deloria Jr. 1995; Deloria et al. 1999; Hester and Cheney 2001). This is why (so the argument for 'polycentric epistemologies' or 'polycentric global epistemology' goes) divination, rain-making, rain-discarding, shamanism, sorcery, ceremony, ritual, mysticism, etc. must be acknowledged as ways of knowing alongside animal husbandry, botany, medicine, mathematics, tool-making, and the like (Maffie 2009, 60).

David Hall and Roger Ames contend that those epistemologies that might be called 'way-seeking', as opposed to 'truth-seeking',

are concerned neither with truth, true belief nor truthful representation. Rather, they are concerned with identifying the proper path or appropriate model of conduct that will enable humans to live the kind of life suitable for human beings. (Maffie 2009, 57, emphasis added; see Hall and Ames 1987, 1998)

James Maffie refers to the Mexica (Aztec) concept of neltiliztli (rootedness) as being 'embedded within a larger philosophical conception of human endeavours that [he sees] as path-seeking or "praxis-guiding" (to borrow from Rosemont Jr. et al. $[2014,155]$ ) rather than truth-seeking' (Maffie 2014, 161, 162). For many (if not most) indigenous Africans, Asians and Oceanians, for example, this involves

living harmoniously with one's social surroundings. Correspondence truth plays no role in this endeavour. One aims for a life of authenticity, genuineness, rectitude and wholeness - not knowledge defined as justified true belief. [This kind of] epistemology seeks to identify the kind of practical know-how needed for following this path. (Maffie 2009, 57)

This basic orientation is echoed in a recent symposium anchored by Henry Rosemont, Jr. (Maffie, Maraldo and Sonam Thakchoe are the other participants.) The argument is that traditions outside the Anglo-European mainstream

seem to draw on an integrated view of thinking, feeling, and living a human life. For their practitioners, truth is less of a correspondence with a given external reality. In fact, it enables human beings to strike the right path in living good, social lives. (Rosemont Jr. et al. 2014, 150) 
According to Wasuji, the 'correspondence between thought and external things ... does not deserve the name of truth if it does derive from a practiced correspondence between words and acts, a correspondence shared in a community' (Maraldo 2014, 172). Wasuji argues that truth is reached when truthfulness (or sincerity) informs our judgements. Truth for him is more than correct statement, more than conformity of words with facts.

Wasuji notes that one could intend to deceive but inadvertently describe the facts correctly, and such a description would not constitute truth. Truthfulness depends on preserving a relationship of trust. Put negatively, truth requires not betraying the trust of others. (Maraldo 2014, 172)

Wasuji does not appear to consider the possibility that one can speak sincerely and nonetheless misrepresent the facts.

Speaking about conquest-era Mexica philosophy in particular, Maffie contends that it

lacks such a concept and theory of truth. Truth as correspondence, mirroring, representation, or aboutness plays no role in the Mexica's theory of language. Mexica philosophy embraces instead a concept of well-rootedness ... that derives its meaning from a conceptual cluster that includes: furthering one's ancestral lineage ... and inherited lifeway; arranging, ordering, and balancing one's lifeway; as well as appropriateness, rectitude, authenticity, and the ability to be assimilated into one's lifeway. (Maffie 2014, 161)

These responses seem to contain a number of confusions and errors. The first is the failure to distinguish between epistemology on the one hand and ethics (in this case virtue ethics) on the other. While there are important connections between the two (as a quick survey of the field of social epistemology will show), and notwithstanding the conceptual dependence of 'truthfulness' on 'truth', there appears to be little awareness on the part of the authors that they may be committing a category mistake here. It is also unclear whether practical knowledge is wholly devoid of propositional content ${ }^{17}$ (I will return to this point below). Furthermore, identification of the 'proper (or right) path' etc. will almost certainly involve some beliefs about the appropriateness and correctness of this identification. Surely, there must be beliefs about which paths are 'improper', 'wrong', or which models are 'inappropriate', and what counts as 'correct' identification of proper paths and appropriate models. One can quite coherently aim both for 'a life of authenticity, genuineness, rectitude and wholeness' and 'knowledge defined as justified true belief'. The two are not mutually exclusive - quite the contrary. A similar response might be given to Maffie's claim,

Conquest-era indigenous Nahuatl-speaking philosophers in Central Mexico conceived knowing in terms of balance, well-groundedness, moral uprightness, authenticity and disclosingness ... Correspondence truth played no role in their notions of wisdom, knowledge, or right belief. (Maffie 2009, 57)

Finally, the excessive focus on 'correspondence truth' as the standard Western (or Northern) conception of truth may be misguided. There are different theories of truth, all with distinct strengths and weaknesses. Many theorists would probably 
contend that only one theory can be correct. Yet, as David Bridges has argued, quite compellingly, different theories of truth might be seen to fit different areas of knowledge or (educational) research models. For example, the correspondence theory of truth seems to have its natural home in at least some of the empirical sciences, while the coherence theory of truth pertains, for example, to mathematics and symbolic logic. The pragmatist theory (truth as 'what works') is appropriate for technology and certain applied sciences, whereas the consensus conception of truth has a distinct appeal in the realm of social and political decision-making (Bridges 1999). It follows that the assumption of correspondence truth being the default conception within the Western philosophical canon is rather narrow and, in fact, mistaken.

It has been suggested (by Deloria Jr., ${ }^{18}$ Deloria et al., and Hester and Cheney) that indigenous North American philosophies treat cognitive states as maps rather than as beliefs. Native Americans adopt an agnostic attitude towards the correspondence truth of their maps seeing as they are concerned only with the utility of maps as practical action-guides. Native American philosophy does not focus upon belief and thus worries not about correspondence truth of belief. Native Americans focus upon practices and adopt an attitude of non-belief (i.e. neither belief nor disbelief) towards their practices. Knowing is likewise practical. It is not a species of belief or theoretical attitude towards some abstract proposition, justified or otherwise. (Maffie 2009, 57; emphasis added)

In response, one might point out that there is nothing incoherent about treating beliefs as maps. John White does this in the chapter 'Beliefs: Maps by which we steer' in his book The child's mind (White 2002). Moreover, while propositional and practical knowledge are clearly distinct, and one does not collapse into the other, they are considerably more intimately connected than the above-named authors are willing to acknowledge. Surely, Native Americans will almost certainly entertain certain beliefs about, for example, the utility and sustainability of their practices. Similarly, if indigenous 'Amazonia philosophy ... conceives knowledge in terms of the trustworthy, responsible, and careful ordering and arranging of things' and 'eschews broad, overarching, abstract conceptions of truth such as correspondence between propositions and the world' (Maffie 2009, 57), it is difficult to see how one is to make sense of trustworthiness, ordering, arranging etc. in the absence of truth-based knowledge - especially given their justificatory role.

Maffie is arguably correct in pointing out that 'Western truth-seeking epistemologies (beginning with Plato and Aristotle) ... standardly define knowledge in terms of theoretical contemplation rather than practical application' $(57,58)$. After all, this is what makes them 'epistemologies'. But if one accepts, merely for the sake of argument, that there is an undesirable bias involved here, one could direct a similar complaint towards Maffie - who focuses on one (practical knowledge) at the expense of another (propositional knowledge). He keeps returning to this dichotomy:

$\ldots$ it is common for [those working in non-Anglo-European traditions] to reject what they see as Western philosophy's ... obsession with truth (as correspondence), belief, 
and worldview. What matters most to indigenous North Americans, for example, is how one lives - not what one believes. Indigenous North American philosophy is practice-centred ... (58, 59; emphasis added)

To repeat: it is difficult to see how views about how one lives or ought to live, what one practices or ought to practice etc., can be held in the absence of belief (i.e. beliefs about the utility, appropriateness and sustainability of one's practices, life, etc.) and of the corresponding desire for one's beliefs to be not only justified but also true.

\section{Conclusion: truth matters}

There appears to be one particular avenue open to advocates of 'way-seeking' philosophies and defenders of 'polycentric global epistemology'.'Knowledge' from an indigenous or aboriginal perspective, according to Maffie,

concerns how one conducts oneself in the world. It is not about producing rational arguments or deductive-nomological explanations, and the inability to produce these is not considered an epistemological shortcoming. Indeed, it is precisely the insistence upon rational proofs that is typically considered a shortcoming. Hence the very idea of discursively refuting [Western critics] is misplaced since it appeals to notions of propositional truth and falsity that these philosophies reject. (59)

How can one offer a response here that will not display the much-maligned rationality and discursiveness? Maffie's intended knock-down argument will lead to exactly the kind of impasse illustrated in the following pertinent excerpt from a play by Bertolt Brecht. Although this parable is ostensibly about reality, and our perception of it, it also serves as a fitting epitaph to the discussion of the fate of truth with which I began this paper. In other words, the parable can also be taken to pose questions around the nature of knowledge, realism vs. constructivism, and objectivity-vs.-subjectivity of truth and truth-claims. The very reason why an answer has not been furnished actually constitutes the answer - and directs us away from subjectivism, relativism and constructivism.

The teacher: Si Fu, name the central questions of philosophy!

Si Fu: $\quad$ Are things outside of us, for themselves, also without us, or are the things within us, for ourselves, not without us?

The teacher: Which opinion is the correct one?

Si Fu: $\quad$ No verdict has been reached yet.

The teacher: What was the latest tendency among the majority of our philosophers?

Si Fu: $\quad$ The things are outside of us, for themselves, also without us.

The teacher: Why did the question remain unsolved?

Si Fu: $\quad$ The conference that was supposed to yield the final verdict took place, as it has done for the past two hundred years, in the monastery Mi Sang, on the banks of the Yellow River. The question was: Is the Yellow River 
real, or does it exist only in people's heads? During the conference, however, there was a melting of snow in the mountains, and the Yellow River rose above its banks and swept away the monastery Mi Sang and all conference participants. The proof that the things are outside of us, for themselves, also without us, therefore, has not been furnished. (Brecht 1967-1969, 36; translation mine)

Contra John Keats, truth is not necessarily beautiful: in fact, it is often brutal, ugly and disgusting. We also do not always love truth: on balance, perhaps our lives would seem to be more pleasant and perhaps even more bearable without it. What, then, is it about truth that makes it so important and that renders its absence a calamity? According to Keyes (2004),

Post-truthfulness ... erodes the foundation of trust that underlies any healthy civilization. When enough of us peddle fantasy as fact, society loses its grounding in reality. Society would crumble altogether if we assumed others were as likely to dissemble as tell the truth. We are perilously close to that point.

Without an epistemological premium placed on truth and without an ethical premium placed on truthfulness, society on any large scale could not function and would in all likelihood break down completely. If we could not know as a matter of course whether or not someone was telling the truth, the social fabric would simply be eroded - or society would not be possible in the first place. 'The truth' may be the world's secret - but we can learn to avoid falsehoods and error and, in so doing, get closer to the way things really are ... or were, for that matter.

\section{Notes}

1. https://en.oxforddictionaries.com/word-of-the-year/word-of-the-year-2016 (accessed 13 February 2017).

2. http://www.richardcorbett.org.uk/long-list-leave-lies/ (accessed 21 February 2017). See also http://brexitlies.com/http://brexitlies.com/. Incidentally, this is not to imply that the 'Stay' campaign operated without resorting to lies and fabrications.

3. In January 2017, Trump delivered a largely self-referential speech that included an untruthful claim that his inauguration was better attended than those of Barack Obama. He also made the astounding claim so belied by the evidence -'I love honesty'. (Here, too, I do not mean to imply that Hilary Clinton's campaign was completely devoid of untruths.)

4. http://www.politifact.com/personalities/donald-trump/ (accessed 23 February 2017). 'Liar liar pants on fire' is a phrase that children like to use when someone is suspected of lying.

5. https://www.washingtonpost.com/graphics/politics/trump-claims/ (accessed 23 February 2017).

6. Alexander Gauland of the German right-wing party Alternative für Deutschland (AfD) asserted recently that the German government is trying to replace the German people with migrants. It is difficult to prove or disprove this kind of statement. But this does not matter to AfD supporters and sympathizers: what matters is that Gauland has articulated what they are feeling - in this case, what they fear or dislike. 
7. http://www.motherjones.com/kevin-drum/2015/11/fabulous-memory-donald-trump (accessed 10 May 2017).

8. https://www.youtube.com/watch?v=D68fvcCG44s (accessed 11 March 2017).

9. Canada was one of the countries to offer help US scientists protect climate change data (http://www.cbc.ca/radio/asithappens/as-it-happens-wednesday-edition-1.3896080/ canadians-help-u-s-scientists-protect-climate-change-data-1.3896089 (accessed 11 March 2017).

10. In fact, Trump himself tweeted that climate change is a hoax created by the Chinese to make US manufacturing non-competitive.

11. This echoes the radical postmodern view that 'knowledge can never be more than just a story' (Pennock 2010, 762) and that 'all narratives are equal and allows no special privilege to any truth claim over any other' (773).

12. http://www.latimes.com/opinion/op-ed/la-oe-barnett-nature-alternative-facts20170210-story.html (accessed 11 March 2017).

13. http://thebreakthrough.org/index.php/journal/past-issues/issue-3/post-truthpluralism (accessed 23 February 2017).

14. https://ed.stanford.edu/news/stanford-researchers-find-students-have-troublejudging-credibility-information-online (accessed 21 May 2017).

15. To take an important example, Mark Zuckerberg and Facebook clearly have a responsibility to filter out fake news, notwithstanding their invocation of the impossibility of such a task. After all, they have developed algorithms for crowdsourcing, eliminating pornographic content, and for tailoring feeds relating to users' interests and attitudes.

16. http://l.email.newyorktimes.com/rts/go2.aspx?h=114,742\&tp=i-H43-A3-3D5-MQQgg1y-3ZiWe-1c-MLU9w-YOTV\&x=i-H43-A3-3D5-MQQgg-1y-3ZiWe-1c-MLU9w-YOTV (accessed 27 February 2017).

17. According to Maffie, 'philosophic reflection for the Mexica is first and foremost a practical endeavour concerned with creating a good life, not a theoretical endeavour concerned with discovering truth' (Maffie 2014, 164). 'Mexica philosophy speaks not of propositional belief ("belief that") and knowledge ("knowledge that") but of "ohtlatoca" ("following a path") and "know how" respectively' (166). 'Right-path knowing ("tlamatiliztli") ... is understood in terms of skill, competence, and the ability to make things happen - and not in terms of the intellectual apprehension of truths or states of affairs' $(166,167)$.

18. One of Vine Deloria Jr's chief targets in his book Red earth, white lies: Native Americans and the myth of scientific fact (1995) is the theory, embraced by a vast majority of archaeologists, that America's original, 'indigenous' inhabitants originally came from Asia across the Bering Strait more than 10,000 years ago. Dismissing this account as 'scientific folklore', Deloria presents a version of the popular creationist view that Native Americans have always lived in the Americas, after emerging onto the earth's surface from a subterranean world of spirits. Deloria, similarly - employing arguments strongly reminiscent of those advanced by Christian fundamentalists, rejects the theory of evolution (like the Bering Strait hypothesis) as unsubstantiated dogma. 'Science is the dominant religion', he said in an interview. In attempting to salvage their own dogmatic accounts, he said, archaeologists 'are fudging considerably so that their general interpretation does not give us much confidence, and some Indian accounts may be more accurate' (reported in Johnson 1996, 2). 


\section{Acknowledgement}

This paper was first presented in the Wednesday Seminar Series at the Institute of Education, London, in March 2017. I am grateful to all participants for their incisive questions and generative feedback. I am indebted, further, to David Bridges and to Harvey Siegel for continuing inspiration and encouragement.

\section{Disclosure statement}

No potential conflict of interest was reported by the author.

\section{References}

Arendt, H. 1967. "Truth and Politics." The New Yorker, February 25, 1-15. Accessed February 14, 2017. https://idanlandau.files.wordpress.com/2014/12/arendt-truth-and-politics.pdf Arendt, H. 1998. The Human Condition. 2nd ed. Chicago, IL: University of Chicago Press. Beiner, R. 2008. "Rereading 'Truth and Politics.' Philosophy \& Social Criticism 34 (1-2): 123-136.

Brecht, B. 1967-1969. “Turandot oder Der Kongress der Weißwäscher." [Turandot or The Congress of Whitewashers.] In Stücke [Plays], edited by B. Brecht and E. Hauptmann, Vol. 14, xx-xx. Berlin \& Weimar: Aufbau Verlag.

Bridges, D. 1999. “Educational Research: Pursuit of Truth or Flight of Fancy?" British Educational Research Journal 25 (5): 597-616.

Code, L. 2012. "Taking Subjectivity into Account." In Education, Culture and Epistemological Diversity: Mapping a Contested Terrain, edited by C. W. Ruitenberg and D. C. Phillips, 85-100. Dordrecht: Springer.

Cross, M., and A. Ndofirepi, eds. 2017. Knowledge and Change in the African Universities. Rotterdam: Sense Publishers.

Deacon, M. 2016. "In a World of Post-truth Politics, Andrea Leadsom Will Make the Perfect PM." The Daily Telegraph, July 9, 2016. Accessed July 11, 2016. http://www.telegraph.co.uk/ news/2016/07/09/in-a-world-of-post-truth-politics-andrea-leadsom-will-make-the-p/

Deloria Jr., V. 1995. Red Earth, White Lies. Native Americans and the Myth of Scientific Fact. New York: Scribner.

Deloria, B., K. Foehner, and S. Scinta, eds. 1999. Spirit and Reason. A Vine Deloria Jr. Reader. Golden: Fulcrum Publishers.

De Sousa Santos, B., ed. 2007. Another Knowledge Is Possible. Beyond Northern Epistemologies. London: Verso.

Frankfurt, H. G. 2005. On Bullshit. Princeton, NJ: Princeton University Press.

Hall, D., and R. Ames. 1987. Thinking Through Confucius. Albany: State University Press of New York.

Hall, D., and R. Ames. 1998. Thinking from the Han. Self, Truth and Transcendence in Chinese and Western Culture. Albany: State University Press of New York.

Harding, S. 1991. Whose Science? Whose Knowledge? Ithaca, NY: Cornell University Press.

Harding, S. 1996. "Gendered Ways of Knowing and the 'Epistemological Crisis' of the West." In Knowledge, Difference, and Power: Essays Inspired by Women's Ways of Knowing, edited by N. R. Goldberger, J. M. Tarule, B. M. Clinchy, and M. F. Belenky, 431-454. New York: Basic Books.

Heer, J. 2015. “Donald Trump Is Not a Liar. He's Something Worse: He's a Bullshit Artist." The New Republic. Accessed February 25, 2017. https://newrepublic.com/article/124803/donaldtrump-not-liar 
Hester, L., and J. Cheney. 2001. "Truth and Native American Epistemology." Social Epistemology 15 (4): 319-334.

Higgins, K. 2013. "Post-truth Pluralism: The Unlikely Wisdom of Nietzsche." Breakthrough Journal, Summer. Accessed February 25, 2017. http://thebreakthrough.org/index.php/journal/pastissues/issue-3/post-truth-pluralism

Johnson, G. 1996. "Indian Tribes' Creationists Thwart Archaeologists." The New York Times, October 22, A1. Accessed February 25, 2017. http://query.nytimes.com/gst/fullpage. html?res=9C06EFD71730F931A15753C1A960958260\&sec=\&spon=\&pagewanted=print

Keyes, R. 2004. The Post-truth Era: Dishonesty and Deception in Contemporary Life. New York: St. Martin's. Accessed February 13, 2017. http://www.ralphkeyes.com/the-post-truth-era/

Levisohn, J. A., and D. C. Phillips. 2012. "Charting the Reefs: A Map of Multicultural Epistemology." In Education, Culture and Epistemological Diversity: Mapping a Contested Terrain, edited by C. W. Ruitenberg and D. C. Phillips, 39-63. Dordrecht: Springer.

Maffie, J. 2009. "In the End, We Have the Gatling Gun, and They Have Not': Future Prospects of Indigenous Knowledges." Futures 41: 53-65.

Maffie, J. 2014. "Reflections on Henry Rosemont's 'Introductory Statement."' Confluence: Online Journal of World Philosophies 1: 161-167.

Maraldo, J. 2014. "Truth Is Truthfulness: The Japanese Concept of Makoto." Confluence: Online Journal of World Philosophies 1: 168-185.

Pennock, R. T. 2010. "The Postmodern Sin of Intelligent Design Creation." Science \& Education 19 (6-8): 757-778.

Quale, A. 2008. Radical Constructivism: A Relativist Epistemic Approach to Science Education. Rotterdam: Sense.

Roberts, R. 2010. “Post-truth Politics." Grist, April 1, 2010. Accessed July 11, 2016. http://grist.org/ article/2010-03-30-post-truth-politics/

Rosemont Jr., H. 2014a. "Introductory Statement." Confluence: Online Journal of World Philosophies 1: 151-157.

Rosemont Jr., H. 2014b. "Reply: Truth as Truthfulness." Confluence: Online Journal of World Philosophies 1: 205-212.

Rosemont Jr., H., J. Maffie, J. Maraldo, and S. Thakchoe. 2014. "Symposium: Does the Concept of 'Truth' Have Value in the Pursuit of Cross-cultural Philosophy?" Confluence 1: 149-217.

Seepe, S., ed. 2004. Towards an African Identity of Higher Education. Pretoria:Vista University and Skotaville Media.

Siegel, H. 2012. “Epistemological Diversity and Education Research: Much Ado About Nothing Much?" In Education, Culture and Epistemological Diversity: Mapping a Contested Terrain, edited by C. W. Ruitenberg and D. C. Phillips, 65-84. Dordrecht: Springer.

Thakchoe, S. 2014. "Tibetan Reflections on the Value of Truth in Cross-cultural Philosophy." Confluence: Online Journal of World Philosophies 1: 186-204.

White, J. 2002. The Child's Mind. London: Routledge Falmer. 